\title{
ANALISIS PERKEMBANGAN KURIKULUM DI INDONESIA \\ (Sebuah Tinjauan Desain dan Pendekatan)
}

Muhammad Nurhalim

Dosen Jurusan Tarbiyah STAIN Purwokerto

\begin{abstract}
Each curriculum should be organized and developed to fit the needs of the community so the curriculum is always required to be dynamic to follow the development of society and science, to change, to be corrected, even to have a renewal of continuous improvement. In the history of national curriculum development in Indonesia, the education in Indonesia has experienced several changes in the curriculum in 1947, 1950, 1968, 1975, 1984, 1994, 1999 supplement, 2004, and 2006. If the development of the curriculum is being observed, there are two main characteristics that could mark the changing those are from centralized to decentralized and from teacher to student centered. This paper attempts to examine the curriculum developments analysis in the review of design and approach.

Keywords: curriculum development in Indonesia, the design and approach.
\end{abstract}

\section{Pendahuluan}

Guna melestarikan sistem nilai yang berkembang dalam kehidupan berbangsa dan bernegara, maka kunci utamanya adalah dengan melaksanakan pendidikan yang dibangun dalam berbagai ranah secara seimbang baik berupa pemberian ilmu pengetahuan (ranah kognitif), pembentukan sikap (ranah afektif), perilaku (ranah psikomotor) dan kepribadian bagi peserta didik. (Sujarwo, 2007:1). Sehingga daripada itu, membangun pendidikan pada ketiga ranah dan kepribadian tersebut merupakan sebuah keharusan bagi pemerintah jika ingin warga negaranya mampu berada dalam sistem nilai yang komprehensif sesuai dengai sistem nilai yang dianut dalam negara.

Untuk mengetahui seberapa baik pendidikan suatu bangsa dalam membentuk sistem nilai tersebut, maka secara umum dapat dilihat dari 
bagaimana pemerintah mendesain kurikulum yang digunakan, karena kurikulum adalah blueprint dari pendidikan. Kurikulum dikatakan efektif salah satu cirinya adalah manakala kurikulum tersebut mampu menyiapkan lulusan sesuai kebutuhan dan tuntutan masyarakat. Oleh karena itu, pegembangan dan pembaharuan kurikulum berdasar tuntutan dan kebutuhan masyarakat tersebut adalah suatu keharusan. Kurikulum harus bersifat antisipatif dan adaptif (mampu menyesuaikan diri) terhadap perubahan masyarakat itu sehingga kurikulum dituntut selalu dinamis mengikuti perkembangan masyarakat dan ilmu pengetahuan, dan cenderung mengalami perubahan, perbaikan bahkan pembaharuan terus menerus. Atau dalam arti lain masyarakat terus berubah dan berbenah begitupun kurikulum juga harus berubah dan berbenah.

Dalam sejarah kurikulum Nasional di Indonesia, kurikulum telah mengalami beberapa perubahan baik dalam orientasi, pendekatan bahkan filosofinya. Terjadinya perubahan kurikulum tersebut bukanlah suatu hal yang mengherankan karena sebagaimana salah satu prinsipnya yaitu prinsip relevansi, maka sebuah kurikulum harus mampu secara dinamis untuk dapat menyesuaikan dengan tuntutan dan perubahan yang terjadi di masyarakat dimana kurikulum tersebut dilaksanakan. (Sukmadinata, 2007). Dengan memegang teguh pada prinsi ini, maka output yang dihasilkan dari sebuah proses aktualisasi kurikulum dapat secara cepat dan tepat berinteraksi dan beradaptasi dengan zamannya.

\section{Perkembangan Kurikulum}

Berdasarkan catatan sejarah pendidikan di Indonesia, Semenjak dibukukannya kurikulum tahun 1968 dan sebelumnya telah ada kurikulum 1947 dan 1952 dan 1964, kurikulum telah mengalami enam kali perubahan yaitu tahun 1975, kemudian disusul perubahan per sepuluh tahunan yaitu 1984, 1994 dan 2004, serta yang terakhir adalah tahun 2006. (Soekisno, 2010). Adapun secara garis beras perkembangan kurikulum setelah dibukukan dapat dilihat sebagaimana berikut:

\section{- Kurikulum Tahun 1968}

Pada kurikulum 1968 ini, proses dan aktifitas pembelajaran dititikberatkan pada program Pancawardhana sebagaimana pada 
kurikulum tahun 1964. Pancawardhana berarti kurikulum yang bertujuan untuk 5 hal pokok, yaitu pengembangan kecerdasan, moral, keprigelan, emosional, dan jasmani. Sehingga dalam konsep ini kurikulum harus mampu mengembangkan daya cipta (bagaimana berfikir cerdas), rasa (bagaimana mengolah dan menggunakan rasa terdalam manusia), karsa (bagaimana memupuk keinginan dan motifasi), karya (bagiaman berbuat dalam bentuk nyata), dan moral (bagaimana berperilaku baik). (Soekisno, 2010). Kurikulum pada tahun 1968 ini merupakan kurikulum pada masa awal-awal orde baru sehingga kelima unsur dalam Pancawardhana tersebut harus menjadikan manusia indonesia yang pancasilais yang berdasar kepada kelima sila pancasila, yaitu Ketuhanan Yang Maha Esa, Kemanusiaan yang adil dan beradab, Persatuan Indonesia, Kerakyatan yang Dipimpin oleh Hikmat Kebijaksanaan dalam Permusyawaratan/Perwakilan dan Keadilan Sosial Bagi seluruh Rakyat Indonesia. Dan untuk mencapai tujuan-tujuan tersebut, setiap mata pelajaran dikelompokkan dalam tiga kelompok besar, yaitu: kelompok kecakapan khusus, kelompok pembinaan pengetahuan dasar dan kelompok pembinaan pancasila. (Hendra, 2010)

Kurikulum 1968 merupakan kurikulum bersifat sentralistik, dalam artian kurikulum merupakan kebijakan yang telah ditetapkan oleh pemerintah sedangkan sekolah hanya sebagai pelaksana dari kebijakan yang telah ditetapkan. Pendekatan yang digunakan menggunakan pendekatan subject matter atau berpusat pada ilmu pengetahuan. Implikasi dari pendekatan ini adalah bahwa proses pembelajaran lebih berorientasi pada penguasaan materi pembelajaran sehingga peran siswa dalam proses pembelajaran sangatlah pasif.

\section{- Kurikulum Tahun 1975}

Sebagaimana kurikulum sebelumnya, kurikulum 1975 merupakan kurikulum yang bersifat sentralistik atau dibuat oleh pemerintah pusat dan sekolah tinggal melaksanakan. Untuk memahami kurikulum ini maka dapat dilihat dari orientasi yang digunakan, mata pelajaran yang diberikan, proses pembelajaran yang dilakukan, pendekatan yang dipakai dan proses evaluasi yang diterapkan. Adapun penjelasannya 
adalah sebagaimana berikut:

Pertama, Orientasi yang digunakan dalam kurikulum ini adalah orientasi tujuan. (Hendra, 2010). Orientasi tujuan ini maksudnya bahwa setiap pembelajaran harus diupayakan semaksimal mungkin untuk mencapai tujuan yang ditetapkan. Dalam pelaksanaannya, setiap tujuan dijabarkan ke dalam tujuan umum dan tujuan khusus yang spesifik dan terukur dalam bentuk perbuatan yang dapat dilakukan oleh siswa. Dengan berorientasi pada tujuan ini, setiap guru dituntut untuk memahami setiap tujuan yang ditetapkan dan bagaimana menerapkannya dalam proses pembelajaran di kelas.

Kedua, mata pelajaran yang disajikan terdiri dari Bidang studi. Jumlah mata pelajaran untuk SD ada 9 bidang sedangkan untuk SMP dan SMA ada 11 bidang. (Ridwanudin, 2010) Khusus untuk mencetak manusia pancasilais, pencapaian yang diharapkan dibebankan secara langsung pada tiga mata pelajaran, yaitu Pendidikan Moral Pancasila, pendidikan agama dan IPS.

Ketiga, proses pembelajaran bersifat integratif, artinya setiap mata pelajaran yang diberikan kesemuanya harus secara bersamasama mendukung untuk tercapainya tujuan akhir pendidikan. Dalam implementasinya kurikulum ini banyak menekankan kepada pemberian stimulus-respon atau menganut aliran psikologi behaviorisme serta latihan dengan mempertimbangkan efisiensi dan efektivitas penggunaan kemampuan sekolah dan guru serta efisiensi waktu. (Hendra, 2010)

Keempat, Pendekatan yang dipakai dalam kurikulum adalah pendekatan sistem yang disebut dengan PPSI (Prosedur Pengembangan Sistem Instruksional). (Hendra, 2010) Pendekatan sistem ini berarti bahwa pembelajaran adalah sebuah interaksi antar komponenkomponen pembelajaran (komponen tujuan pelajaran, komponen materi, komponen alat pelajaran, komponen alat evaluasi, dan komponen metode pengajaran) yang saling terkait antara satu komponen dengan komponen yang lain untuk mencapai tujuan tertentu. Dalam pendekatan sistem ini minimal dibutuhkan tiga kemampuan (ability), yaitu: (1) kemampuan merumuskan tujuan-tujuan secara operasional, (2) kemampuan mengembangkan deskripsi tugas-tugas secara lengkap 
dan akurat, dan (3) kemampuan melaksanakan analisis tugas-tugas. (Hamalik, 2005: 9).

Kelima, evaluasi formatif pada setiap akhir sub bab dan evaluasi sumatif pada akhir bab, sehingga evaluasinya terdiri dari evaluasi antara dan evaluasi akhir.

\section{- Kurikulum Tahun 1984}

Kurikulum 1984 merupakan kurikulum penyempurna kurikulum sebelumnya. Dalam kurikulum ini, teori belajarnya tidak lagi menggunkan behavioris tetapi lebih merangkul teori-teori humanism yang berpusat pada peserta didik dan berorientasi kepada proses. Hal ini dapat dilihat dari pendekatan yang dipakai dalam kurikulum ini, yaitu pendekatan keterampilan proses (Cara Belajar Siswa Aktif/ CBSA). CBSA adalah pendekatan yang digunakan dalam proses pembelajaran yang memberikan kesempatan kepada setiap siswa untuk terlibat secara aktif. Keterlibatan disini lebih ditekankan pada keterlibatan aktif mental siswa, walaupun juga tidak mengesampingkan keterlibatan fisik dan intelektual. Sebagaimana dikatakan Sulo (2010) yang mengutip Raka Joni bahwa keaktifan siswa disini bukanlah menafikan keaktifan fihak guru, tetapi kedua-duanya sama-sama aktif. Sehingga dengan demikian, Pendekatan CBSA menekankan keaktifan semua pihak yang terlibat dalam proses pembelajaran tersebut.

Selain berpusat pada peserta didik dalam CBSA, kurikulum ini juga berorientasi kepada tujuan instruksional. Artinya bahwa apa yang disampaikan dan dilakukan dalam proses belajar mengajar di kelas harus mengacu pada tujuan yang ditetapkan karena asumsi dasarnya adalah bahwa pemberian pengalaman belajar di dalam kelas sangatlah terbatas sehingga proses pembelajaran harus benar-benar fungsional dan efektif untuk mencapai tujuan ynag ditetapkan. Oleh karena itu, sebelum menentukan materi maupun proses pembelajaran, maka guru harus merumuskan terlebih dahulu tujuan yang diharapkan dari serangkaian proses yang akan dilakukan. (Hendra, 2010).

Dalam kurikulum ini, materi disampaikan dengan model sekuens semakin meluas seperti sebuah spiral. Sebagaimana dikatakan Sukmadinata (2007:106) model ini dikembangkan oleh Bruner 
(1960) yang memusatkan bahan ajar pada topik atau pokok bahasan tertentu. Dari pokok bahasan tersebut bahan diperluas dan diperdalam. Pokok bahasan biasanya dipilih sesuatu yang popular dan sederhana, kemudian diperdalam dan diperluas dengan materi yang lebih komplek. Materi atau bahan pelajaran disampaikan dalam bentuk mata pelajaran. Adapun salah satu contoh Struktur Kurikulum 1984 untuk Madrasah Ibtidaiyah (Tingkat Dasar) adalah Qur'an-Hadits, Aqidah-Akhlak, Fiqih, Sejarah Islam, Bahasa Arab, PMP, PSPB, Bahasa Indonesia, Ilmu Pengetahuan sosial, Matematika, Ilmu Pengetahuan Alam, Olah Raga dan Kesehatan, Pendidikan Jasmani, Keterampilan Khusus, dan Bahasa Daerah dengan jumlah jam pelajaran 29 jam (untuk kelas 1, 2 dan 3) dan 40 jam (untuk kelas 4, 5 dan 6).

\section{- Kurikulum Tahun 1994}

Sebenarnya kurikulum 1994 merupakan kurikulum penyempurnaan dari kurikulum 1984. Dalam proses pembelajarannya kurikulum 94 masih menggunakan pendekatan CBSA (Cara Belajar Siswa Aktif) tetapi telah mengenal istilah istilah life skill atau pendidikan kecakapan hidup. Pendidikan kecakapan hidup sebagaimana dikatakan Sukamara (2005:22) yang mengutip Depdiknas, adalah suatu kecakapan yang harus dimiliki seseorang untuk berani menghadapi problem hidup dan kehidupan dengan wajar tanpa merasa tertekan, kemudian dengan kecakapan tersebut siswa secara proaktif dan kreatif dapat mencari serta menemukan solusi dri setiap permasalahan sehingga mampu mengatasinya. Berkaitan dengan life skill ini, Susiwi (2007) menjelaskan bahwa ada dua macam kecakapan hidup yaitu : (1) Kecakapan Hidup Generik (General life skill, GLS) yang terdiri dari Kecakapan Personal (Personal Skill), Kecakapan Berpikir (Thinking Skill), Kecakapan Sosial (Social Skill), dan (2) Kecakapan Hidup Spesifik (Specific life skill, SLS) yang terdiri dari Kecakapan Akademik (Academic Skill) dan Kecakapan Vokasional / Kejuruan (Vocational Skill)

Dalam kurikulum 1994, kurikulum ditetapkan oleh pemerintah untuk setiap wilayah di Indonesia, artinya kurikulum ini bersifat sentralistis. Materi pelajaran cukup banyak yang terdiri dari: (1) Pendidikan pancasila dan kewarganegaraan; (2) Pendidikan agama; (3) 
Bahasa Indonesia; (4) Matematika; (5) Ilmu Pengetahuan Alam (IPA); (6) Ilmu Pengetahuan Sosial (IPS); (7) Kerajinan Tangan dan Kesenian; (8) Pendidikan Jasmani dan Kesehatan; (9) Bahasa Inggris, dan (10) Muatan Lokal (sejumlah mata pelajaran). Isi kurikulum secara umum terdiri atas $80 \%$ muatan inti dan $20 \%$ muatan local (muatan nasional dan daerah). Dan kurikulum ini pernah mengalami pemangkasan materi overlopping dengan suplemen 1999 sebagai penguatan dari materi yang terpangkas. Setiap mata pelajaran tersebut disampaikan secara terpisah. Dalam pengorganisasian materi, pengorganisasian lebih bersifat sekuens logis dan psikologis. Sebagaimana dikatakan Sukmadinata (2007: 106), sekuens logis bahan ajar dimulai dari yang sederhana ke yang komplek, dari yang nyata ke yang abstrak, dari benda kepada teori, dari fungsi kepada struktur, sedangkan menurut sekuens psikologis materi pembelajaran dari keseluruhan kepada bagian.

Sedangkan dalam proses pembelajaran sebagaimana pendekatan CBSA, maka proses pembelajaran diupayakan bagaimana peserta didik dapat secara aktif berproses dalam pembelajaran baik secara intelektual, mental, maupun fisik. Dan dalam prosesnya seringkali diadakan pengulangan-pengulangan bagi materi-materi yang dianggap sulit. Ide kurikulum ini sebenarnya ingin menggabungkan antara siswa aktif dan berpusat pada tujuan pembelajaran.

\section{- Kurikulum Tahun 2004}

Kurikulum pada tahun 2004 merupakan resolusi dari kurikulumkurikulum sebelumnya yang dianggap hanya berbasis pada input dan proses sehingga mengarah pada stagnasi pedagogik yang akan sulit untuk beradaptasi dengan tuntutan dan perkembangan ilmu pengetahuan, teknologi dan masyarakat global. Kurikulum ini sering disebut dengan Kurikulum Berbasis Kompetensi (KBK), karena seluruh proses pendidikan di sekolah ditetapkan standarnya berdasar kompetensi yang dikembangkan oleh Badan Standar Nasional Pendidikan (BSNP). Kurikulum Berbasis Kompetensi (KBK) dapat diartikan sebagai suatu konsep kurikulum yang menekankan pada kemampuan melakukan (kompetensi) tugas-tugas dengan standar performansi tertentu, sehingga hasilnya dapat dirasakan peserta didik 
berupa seperangkat kompetensi tertentu. (Mulyasa, 2008: 39). Standarstandar kompetensi tersebut merupakan acuan utama setiap proses yang terjadi di sekolah.

Tujuan utama kurikulum ini adalah memandirikan atau memberdayakan sekolah dalam mengembangkan kompetensi yang akan disampaikan kepada peserta didik, sesuai dengan kondisi lingkungan. (Mulyasa, 2008: 8). Sedangkan komponen pokok kurikulum ini sebagaimana dikatakan Sukamara, (2005: 40-41), yaitu; (1) Kurikulum Dan Hasil Belajar (KHB) yang memuat pengembangan kompetensi peserta didik, (2) Penilaian Berbasis Kelas (PBK) yang memuat prinsip, ssaran dan pelaksanaan penilaian berkelanjutan yang akurat dan konsisten, (3) Kegiatan Belajar Mengajar (KBM) yang memuat gagasan pokok tentang pembelajaran untuk pencapaian kompetensi dan gabungan ilmu paedagogis dan andragogis, (4) Kurikulum berbasis sekolah yang memuat berbagai pola pemberdayaan tenaga kependidikan dan pengembangan sistem informasi kurikulum.

Karakteristik dari kurikulum ini sebagaimana dikatakan Mulyasa (2008: 43) adalah: (1) sistem belajar dengan modul atau panduan yang secara rinci dapat dipelajari siswa secara mandiri, (2) menggunakan keseluruhan sumber belajar baik yang direncanakan (learning resources by design) maupun yang dimanfaatkan (learning resources by utilization), (3) pengalaman lapangan yang melibatkan lingkungan sekolah dan masyarakat, (4) strategi individual personal dengan memandang bahwa setiap individu adalah unik dan berbeda-beda sehingga perlu penanganan yang berbeda pula, (5) kemudahan belajar yang dilakukan dengan kombinasi antara pembelajaran personal individual, pengalaman lapangan dan pembelajaran team, dan (6) belajar tuntas (mastery learning) sehingga tidak ada siswa yang tidak menguasai kompetensi yang ditetapkan. Sedangkan sebagaimana Sukamara (2005: 42) dari apa yang disampaiakn Depdiknas, bahwa karakteristik KBK ini adalah: (1) menekankan pencapaian kompetensi individual dan klasikal, (2) berorientasi pada hasil belajar dan keberagaman, (3) menggunakan vareasi metode pembelajaran, (4) sumber belajar yang digunakan adalah setiap setiap sumber yang memenuhi unsur edukatif, (5) menggunakan penilaian proses dan hasil 
guna pencapaian kompetensi.

Strukturkurikulumagakberbeda setiapjenjang. Untuktingkat Taman Kanak-Kanak terdiri dari tiga kegiatan belajar, yaitu: Pengembangan Moral dan Nilai-Nilai Agama, Pengembangan sosial dan emosiopnal dan Pengembangan Kemampuan Dasar. Untuk tingkat Sekolah dasar terdiri dari: Pendidikan agama, kewarganegaraan, Bahasa Indonesia, matematika, Sains, Pengetahuan Sosial, Kesenian, Keterampilan, dan pendidikan jasmani. Untuk jenjang SMP terdiri dari: Pendidikan Agama, Kewarganegaraan, Bahasa dan Sastra Indonesia, Matematika, Sains, Pengetahuan Sosial, Bahasa Ingris, Pendidikan jasmani, Kesenian, Keterampilan serta Teknologi Informasi dan komunikasi. Sedangkan untuk jenjang SMA dibedakan sesui bidang studi: (1) untuk Program Studi IPA difokuskan pada mata pelajaran Matematika, Fisikia, Kimia dan Biologi dengan penekanan pada prinsip alam dan bersikap ilmian, (2) untuk Program Studi IPS difokuskan pada mata pelajaran Kewarganegaraan, Ekonomi, Sejarah, dan sosiologi dengan penekanan pada pemahaman prinsip kemasyarakatan serta pengembangan potensi peserta didik untuk kedamaian dan kesejahteraan hidup bersama, (3) untuk Program Studi Bahas difokuskan pada mata pelajaran Bahasa dan Sastra Indonesia, Bahasa dan sastra Inggris, Bahas Asing lain, dan teknologi Informasi dan komunikasi dengan penekanan pada prinsip multikultural dan komunikasi efektif. (Mulyasa, 2008: 75-81).

Implementasi Kurikulum Berbasisi Kompetensi di setiap lembaga pendidikan merupakan respon dari kebijakan Depdiknas tentang pelaksanaan Braod Bases Education (BBE) dalam meningkatkan mutu pendidikan. Sehingga implementasi KBK menggunakan konsep BBE yang berorientasi pada life skill (BBE LS) dan berupaya untuk mendayagunakan seluruh potensi sumber belajar yang dimiliki oleh sekolah atau di sekitar sekolah. (Mulyasa, 2008: 27). Orientasi life skill ini sedikit berbeda dengan orientasi life skill pada kurikulum 1994 karena life skill pada kurikulum 2008 ini telah ditekankan pada pengintegrasian secara utuh dan menyeluruh aspek-aspek potensi serta kualifikasi belajar siswa bak berkenaan dengan aspek jasmani maupun rohani, demngan menggunakan pendekatan akal, hati dan naluri serta pendekatan scientism dan eskapistik. (Sukamara 2005: 30-31). 
Jika dilihat dari konsep dasar BBE tersebut, kurikulum berbasis kompetensi merupakan suatu model kurikulum yang menfokuskan sasarannya kepada kemampuan atau penguasaan kompetensi dalam bidan-bidang praktis sehingga kurikulum berbasis kompetensi merupakan model kurikulum yang dikembangkan dari Kurikulum Teknologis.

\section{- Kurikulum Tahun 2006}

Kurikulum 2006 sering disebut dengan Kurikulum Tingkat Satuan Pendidikan (KTSP) yang merupakan kelanjutan dari Kurikulum Berbasis Kompetensi. Sebagaimana dijelaskan oleh BSNP (2006: 5) bahwa KTSP adalah kurikulum operasional yang disusun oleh dan dilaksanakan di masing-masing satuan pendidikan. KTSP terdiri dari tujuan pendidikan tingkat satuan pendidikan, struktur dan muatan kurikulum tingkat satuan pendidikan, kalender pendidikan, dan silabus. Dalam KTSP ini, setiap satuan pendidikan berhak dan diiberi otonom seluas-luasnya untuk mengembangkan kurikulumnya. Sekolah memiliki wewenang luas untuk mengembangkan secara mandiri sesuai dengan kebutuhan dan kondisi masing-masing sekolah.

Kurikulum ini sebagaimana dikatakan Mulyasa (2006: 20) mempunyai kekhasan tersendiri, yaitu: (1) KTSP dikembangkan sesuai dengan kondisi, potensi sekolah/daerah, karakteristik sekolah/daerah, sosial budaya masyarakat setempat, dan karakteristik peserta didik dari satuan pendidikan tersebut, (2) Kurikulum dikembangkan oleh Satuan Pendidikan bersama dengan Komite Sekolah berdasarkan kerangka dasar kurikulum dan kompetensi lulusan di bawah supervisi pendidikan kota/kabupaten atau departemen agama, (3) Mengacu kepada Standar Nasional Pendidikan.

Guna menjabarkan setiap kompetensi dalam pembelajaran, maka sekolah atau guru harus mencermati beberapa hal, yaitu: (1) Standar Kompetensi lulusan (SKL) harus selaras dan serasi dengan Standar Kompetensi (SK) dan Kompetensi Dasar (KD), (2) SKKD harus dijabarkan ke dalam indikator, (3) Pembelajaran harus direncanakan dan dikembangkan berdasarkan standar proses secara matang, (4) Pembelajaran harus menggambarkan tiga standar, yaitu standar isi, 
standar proses dan standar penilaian, (5) Penilaian perlu memperhatikan keseimbangan antar berbagai aspek yang dinilai (kognitif, afektif, psikomotor) dengan mengacu standar penilaian yang ditetapkan oleh Badan Standar Nasional Pendidikan (BSNP). (Mulyasa, 2006: 7)

Struktur kurikulum dalam KTSP ini memuat lima kelompok mata pelajran, yaitu: (1) Kelompok mata pelajaran agama dan akhlak mulia, (2) Kelompok mata pelajaran kewarganegaraan dan kepribadian, (3) Kelompok ilmu pengetahuan dan teknologi, (4) Kelompok mata pelajaran estetika, dan (5) Kelompok mata pelajaran jasmani olahraga, dan kesehatan. (Mulyasa, 2006: 25). Dari kelima kelompok tersebut kemudian dibagi lagi ke dalam mata pelajaran, muatan lokal dan pengembangan diri.

Pendekatan yang dipakai dalam kurikulum ini sebagaimana KBK adalah Competensi Based Curriculum (CBC), Broad Based Curriculum dan Life Skill (kecakapan hidup) yang dikembangkan dari Kurikulum Teknologis. Perbedaan yang menonjol dari KTSP adalah dalam pengembangannya bersifat desentralistik atau menggunakan pengembangan Grass Root Models sedangkan dalam KBK masih menggunakan model pengembangan Administrative models walaupun sudah sedikit memasukkan grassroot model pada sekolah-sekolah piloting project.

Berdasarkan dari berbagai pemaparan desain dan pendekatan kurikulum di atas maka secara sederhana dapat di spesifikkan ciri-ciri atau karakteristik setiap kurikulum sebagaimana berikut:

Kurikulum 68 (tahun 1968) mempunyai karakteristik utama: Merupakan penyempurnaan kurikulum 1964, bentuk dokumen matrik, pendekatan subject matter (kognitif) dan bersifat sentralistik

Kurikulum 75 (tahun 1975) mempunyai karakteristik utama: Pendekatan sistem / PPSI (terminal objective), Muali muncul TIK/TIU, Tujuan instritusional dan tujuan nasional, Teori belajar behaviorism, Bentuk dokumen kurikulum matriks, dan Bersifat sentralistik (sepenuhnya given dari pemerintah)

Kurikulum 84 (tahun 1984) mempunyai karakteristik utama: Revisi dari Kurikulum 75, dilakukan penyederhanaan kolom dalam bentuk dokumen kurikulum, Pendekatan keterampilan proses (CBSA), Teori 
belajar behaviorism dan humanism dan Masih bersifat sentralistik.

Kurikulum 94 (tahun 1994) mempunyai karakteristik utama: Pengembangan bentuk dokumen naratif, Isi kurikulum terdiri atas $80 \%$ muatan inti dan $20 \%$ muatan local (muatan nasional dan daerah), Mengalami pemangkasan materi overlopping, Diadakan suplemen 1999 sebagai penguatan dari materi yang terpangkas, Pendekatan keterampilan proses dan bersifat Sentralistik dan sedikit desentralistik.

Kurikulum Berbasis Kompetensi (tahun2004) mempunyai karakteristik utama: Diterapkan guna mengantisipasi berlakunya UU Otonomi Daerah, Pendekatan transmisi /Konstructivism, Bersifat desentralistik (berdiversifikasi dan berbasis kompetensi dan Dikembangkan oleh Pusat Kurikulum.

Kurikulum Tingkat Satuan Pendidikan (tahun 2006) mempunyai karakteristik utama: Merupakan pengembangan dari kurikulum 2004, KTSP merupakan panduan dan acuan penyusunan kurikulum setiap tingkat satuan pendidikan, Bersifat desentralistik, Berbasis Kompetensi, menggunakan Stadar Nasional, dan Dikembangkan oleh BSNP.

\section{Analisis Kurikulum}

Dilihat dari perkembangan kurikulum tersebut di atas, maka terdapat dua karakteristik utama yang dapat menandai perubahan setiap kurikulum yang terjadi yaitu dari desain model sentralisti /terpusat atau sering disebut dengan desain model Administrative menuju desentralistik atau sering disebut derngan desain model Grass Root dan dari pendekatan belajar teacher centerd (berpusat pada guru) menuju student centered (berpusat pada siswa/pembelajaran aktif). Desain model Administratif adalah sebuah model pengembangan kurikulum yang inisiatifnya berasal dari atas (pemerintah pusat) sedangkan sekolah hanya sebagai pelaksana dari kurikulum yang telah ditetapkan. Biasanya dalam desain ini pemerintah membentuk tim kurikulumk yang terdiri dari praktisi, ahli, dan stake holder pendidikan untuk menentukan desain yang secara nasional dapat diterapkan secara serentak, sehingga tugas sekolah dalam desain ini hanyalah pelaksana dari apa yang telah ditetapkan. Sedangkan Grass Root Model adalah sebuah desain model pengembangan kurikulum 
yang inisiatif pengembangannya berasal dari bawah atau sekolah masingmasing. Dalam desainini sekolah mengembangkan kurikulumnya berdasar dari kondisi riil di lapangan yang kemudian bersama bersama masyarakat menentukan dan mengembangakan kurikulumnya. Tugas atasan atau pemerintah dalam desain grass root ini hanyalah memberikan bimbingan dan dorongan agar kurikulum yang diterapkan mampu diimplementasikan sesuai yang diharapkan. (Sukmadinata, 2007).

Kalau dilihat dari struktur maupun desain kurikulum 68 dan 75, terdapat beberapa kelemahan dan keunggulan dari kurikulum ini. Kelemahan yang mendasar dari kurikulum ini adalah (1) Peserta didik tidak mempunyai kebebasan berekspresi maupun berkreasi karena theacer centered, (2) dikatrenakan desain model pengembangannya terpusat (administrative model), maka akan membunuh kreativitas guru dalam pembelajaran karena guru hanyalah pelaksana terhadap ketetapan dalam kurikulum tanpa tahu pengembangan kurikulumnya (3) pemahaman siswa terhadap mata pelajaran akan terpisah-pisah karena setiap mata pelajaran berdiri sendiri-sendiri, (4) karena penekanan proses pembelajarannya pada segi tujuan kognitif maka segi tujuan afektif dan psikomotornya kurang dapat dicapai secara optimal, dan (5) dikarenakan proses pembelajaran lebih dioptimalkan dengan penggunaan stimulus dan respon, maka secara teoritis tidak akan mampu mengakomodir perbedaan kondisi dan kemampuan peserta didik. Sedangkan keunggulan dari kedua kurikulum ini adalah (1) memudahkan guru dalam organisasi dan implementasi kurikulum karena sudah ada aturan pelaksanaan, materi maupun langkah-langkah yang ditempuh guru dalam melaksanakannnya, dan (2) Memudahkan guru melakukan proses evaluasi karena kurikulumnya berbasis subject matter dan lebih menekankan segi kognitif.

Dalam kurikulum 84, struktur maupun pendekatannya sudah mulai berbeda dari dua kurikulum sebelumnya. Dalam kurikulum ini pendekatan yang dipakai adalah pendekatan matapelajaran tetapi dengan menggunakan keterampilan proses (cara belajar siswa aktif). Dari pendekatan tersebut, secara teori penggunaan pendekatan ini akan memiliki beberapa kelemahan dan keunggulan. Kelemahan dari kurikulum ini adalah: (1) pemahaman siswa terhadap matapelajaran akan terpisah-pisah karena setiap mata pelajaran berdiri sendiri-sendiri, (2) dalam pelaksanaannya 
keterampilan proses memerlukan berbagai keahlian guru tetapi pada kenyataannnya kualitas guru belum memadahi sehingga ketrampilan proses yang coba diangkat oleh kurikulum ini tidak bisa berjalan secara maksimal, (3) membutuhkan dana yang cukup besar terutama di dalam penyediaan media pembelajaran, dan (4) dengan fokus pada keterampilan proses atau keaktifan belajar siswa, maka sering kali guru tidak terfokus pada pencapaian hasil sehingga pengukuran hasil belajar siswa kurang begitu jelas dapat diukur. Sedangkan keunggulan secara teori adalah (1) Siswa diberi kebebasan untuk menemukan pengetahuan sendiri-sendiri, (2) siswa tidak dijustice dengan satu nilai yaitu nilai hasil saja tetapi nilai siswa juga diambil dari proses pembelajaran yang dilakukan sehingga siswa dapat dievaluasi secara adil baik proses maupun hasil, dan (3) akan lebih mengaktifkan guru untuk melakukan-melakukan inovasi-inovasi pembelajaran karena dalam kurikulum ini menuntut guru yang profesional dan berkembang sesuai dengan tuntutan keadaan siswa yang proaktif.

Kurikulum 94 secara umum merupakan penyempurnaan dari kurikulum 84. Kurikulum ini lebih berorientasi pada mata pelajaran, dan diorganisasikan ke dalam mata pelajaran yang terpisah-pisah sehingga sering disebut dengan Separate subject matter. Dari desain yang ditawarkan kurikulum ini ada beberapa kelemahan dan keunggulan yang muncul. Kelemahan yang muncul dari kurikulum ini adalah (1) karena garis-garis program pembelajaran pada kurikulum ini diorganisasikan ke dalam mata pelajaran sesuai dengan disiplin keilmuan, maka hal ini dapat berakibat pada menghilangkan kesatuan bidang studi yang mengakibatkan adanya perolehan yang tidak integral pada siswa, (2) Materi kurikulum yang seragam untuk setiap lembaga pendidikan maka akan mematikan potennsi daerah yang beraneka ragam yang sebetulnya memanfaatkan lembaga pendidikan untuk mengoptimalkan potensi daerah tersebut, dan dengan adanya keseragaman ini akan menghilangkan keunikan setiap daerah karena pada kenyataannya setiap daerah,memiliki karakteristik yang berbeda-beda, (3) Adanya saling ketergantungan antar pokok bahasan antar materi pelajaran sehingga apabila tidak dilakukan dengan team teaching maka tidak terjadi pemahaman yang utuh pada diri siswa (4) karena materi pembelajaran disusun lebih bersifat kepada penguasaan materi pembelajaran atau pengetahuan maka dengan susunan ini akan 
menjadikan pengetahuan yang diperoleh siswa tidak sesuai dengan pengalaman kehidupan sehari-hari peserta didik, dan (5) Karena terlalu banyknya bahan pelajaran yang harus disampaikan maka seringkali tidak sesuai dengan waktu belajar yang disediakan oleh sekolah. Sedangkan kelebihannya adalah lebih memudahkan guru dalam mengorganisasikan materi pelajaran, memudahkan pelaksanaan evaluasi hasil belajar, akan lebih mengaktifkan peran siswa.

Kurikulum 2004 atau kurikulum berbasis kompetensi (KBK) merupakan suatu model kurikulum yang menfokuskan sasarannya kepada kemampuan atau penguasaan kompetensi dalam bidan-bidang praktis terutama bidang pekerjaan. Oleh karena itu, maka kurikulum berbasis kompetensi merupakan model kurikulum yang dikembangkan dari Kurikulum teknologi. Dari desain yang ditawarkan kurikulum ini terdapat beberapa kelemahan dan kelebihan. Kelemahan secara teoritis dari kurikulum ini adalah: (1) siswa hanya diajak berfikir praktis sehingga akan menciptakan manusia-manusia individualis dan materialias, (2) akan sangat menyita waktu banyak untuk menyelesaikan satu materi dengan prakteknya sehingga pengetahuan yang dimiliki siswa sangat terbatas, (3) kurang mengoptimalkan pengembangan bidang analisis siswa karena bersifat pragmatis. Adapun keunggulan dari kurikulum ini adalah akan membiasakan guru dan peserta didik yang terampil dalam bidangnya, membiasakan siswa selalu mencapai kompetensi yang ditetapkan karena berprinsip pada pembelajaran tuntas, dan menjadikan setiap lulusan memperoleh paling tidak standar ketuntasan minimal.

Kurikulum 2006 atau Kurikulum Tingkat Satuan Pendidikan (KTSP) merupakan kurikulum yang dikembangkan oleh setiap satuan pendidikan. Konsep yang ditawarkan dalam kurikulum ini memposisikan setiap satuan pendidikan untuk mengembangkan sendiri-sendiri potensi yang dimiliki. Sehingga akan muncul kelebihan sekaligus kelemahan dari kurikulum ini adalah akan terjadi kesenjangan antar sekolah, disisi lain akan tercipta sekolah-sekolah yang unggul tetapi disisi lain juga akan semakin tercipta sekolah-sekolah yang kurang bermutu karena kekurangan kemampuan dan sumberdaya yang dimiliki. Satu lagi kelemahan dari kurikulum ini adalah, dalam pelaksanannya kurikulum ini harus dilaksanakan berdasarkan delapan satandar pendidikan nasional yaitu standar isi, standar proses, 
standar kompetensi lulusan, standar pendidik dan tenaga kependidikan, standar sarana dan prasarana, standar pengelolaan, standar pembiayaan dan standar penilaian pendidikan, tetapi pada kenyataannya pemerintah baru menetapkan dua standar yaitu standar isi dan standar kompetensi lulusan. Selain itu dengan berbasis kompetensi maka kurikulum ini akan mencetak manusia yang kompeten tetapi disisi lain akan mencetak manusia yang pragmatis, dan mungkin juga individuals.

\section{Penutup}

Untuk menghasilkan sebuah proses pendidikan yang unggul, maka setiap kurikulum harus ditata dan dikembangkan dengan sesuai kebutuhan masyarakat sehingga kurikulum dituntut selalu dinamis mengikuti perkembangan masyarakat dan ilmu pengetahuan, mengalami perubahan, perbaikan bahkan pembaharuan terus menerus. Dalam sejarah perkembangan kurikulum Nasional di Indonesia, pemerintah telah beberapa kali melakukan perubahan baik dalam desain maupun pendekatannya yaitu pada tahun tahun 1947, 1950, 1964, 1968, 1975, 1984, 1994 suplemen 1999, 2004, dan 2006. Kalau dilihat dari perkembangan kurikulum tersebut, terdapat dua karakteristik utama yang dapat menandai perubahan yaitu dari desain model sentralistik (administrative model) menuju desain model desentralistik (grassroot model) dan dari teacher centerd menuju student centered.

Setiap desain kurikulum dari waktu kewaktu selalu terdapat keunggulan dan kelemahan. Tetapi bukan itu sebenarnya yang harus menjadi fokus utama. Yang seharusnya menjadi fokus utama dari sebuah kurikulum adalah bagaimana menyiapkan peserta didiknya agar mampu menghadapi dan menyongsong kehidupannya menjadi lebih baik, bijaksana dan kreatif tanpa harus mengikis kearifan budaya dan norma yang dimiliki bangsa.

\section{Daftar Pustaka}

BSNP, 2006 Panduan Penyusunan Kurikulum Tingkat Satuan Pendidikan Jenjang Pendidikan Dasar Dan Menenga. Jakarta: BSNP 
Hamalik, Oemar. 2005. Perencanaan Pengajaran Berdasarkan Pendekatan Sistem. Jakarta: Bumi Aksara

Hendra, Perkembangan Kurikulum Indonesia [Available at] http:// hendrath-jmr.blogspot.com/2010/05/perkembangan-kurikulumindonesia.html Diunduh 1 Desember 2010.

Mulyasa, E. 2006. Kurikulum Tingkat Satuan Pendidikan: Suatu Panduan Praktis. Bandung : PT Remaja Rosdakarya.

. 2006. Kurikulum Yang Disempurnakan: Pengembangan Standar Kompetensi dan kompetensi dasar . Bandung : PT Remaja Rosdakarya.

. 2008. Kurikulum Berbasis Kompetensi, Konsep Karakteristik dan implementasi. Bandung : PT Remaja Rosdakarya.

Ridwanudin dkk, Perbandingan Kurikulum Pendidikan di Indonesia dalam Tinjauan Historis dan Ideologis [Available at] http:// ridwanudin.wordpress.com/perbandingan-kurikulum/ Diunduh 1 Februari 2010.

Soekisno, R Bambang A. Bagaimanakah Perjalanan Kurikulum Nasional (pada Pendidikan Dasar dan Menengah)? [Available at] http:// rbaryans.wordpress.com/2007/05/16/bagaimanakah-perjalanankurikulum-nasional-pada-pendidikan-dasar-dan-menengah/. Diunduh 5 Desember 2010.

Sujarwo, 2007. Reorientasi Pengembangan Pendidikandi Era Global. [Available at] http://pakguruonline.pendidikan.net. Diunduh 2 Desember 2007

Sukamara, Dian. 2007. Implementasi Program Lifeskill dalam Kurikulum Berbasis Kompetensi Pada Jalur Sekolah. Bandung: Mughni Sejahtera.

Sukmadinata, Nana Syaodih. 2007. Pengembangan Kurikulum, Teori dan Praktik. Bandung: Remaja Rosdakarya

Sulo Lipu La Sulo, Pendekatan Cara Belajar Siswa Aktif (Pendekatan CBSA) [Available at] http://www.google.com/url?sa=t\&rct=j\&q 
$=\&$ esrc $=$ s\&source $=$ web \&cd $=3 \&$ ved $=0$ CDEQFjAC\&url $=h t t p \% 3$ A\%2F\%2Fpjjpgsd.dikti.go.id\%2Ffile.php\%2F1\%2Frepository\% 2Fdikti\%2FMata\%2520Kuliah\%2520Awal\%2FStrategi\%2520Pe mbelajaran\%2FBAC\%2Fstrategi_pembelajaran_unit_4.pdf\&ei= PRsWU9y8GYmMrAfWkoDYBA\&usg=AFQjCNGFU19dLcA HLuhm8biWzK4wxWs5vg\&bvm=bv.62286460,d.bmk\&cad=rja . Diunduh 1 Februari 2010.

Susiwi. 2007. Kecakapan Hidup (Life Skill) "Handout" Mata Kuliah Perencanaan Pembelajaran Kimia. Bandung: Jurusan Pendidikan Kimia, FPMIPA Universitas Pendidikan Indonesia 